\title{
EDUCATORS IN SEARCH OF THE FINE LINE BETWEEN USE AND MISUSE OF NEW TECHNOLOGIES
}

The currently youngest generation of learners has been massively influenced by ubiquitous technology. Due to their developmental cognitive and moral immaturity, decisions about the intensity of their use of ICT lies on the shoulders of their educators who have grown up in a different, pre-globalized world. These adults are often not aware of their insufficiently substantiated approach to their use of ICT in teaching. To become sufficiently informed requires considering various viewpoints, ranging on a continuum from techno-sceptic to techno-utopian. Responsible decisions about the ethical use of ICT can be reached only after considering the issues of the power of ICT as well as the need of coherent research of young learners' needs and teachers' capabilities. The authors share the results of research in various countries. They propose some solutions to this ethical problem, ones they consider suited to reflexive education.

Keywords: Technologies, education, use, ethics.

\section{Introduction}

The benefits of modern technologies are indisputable. For the first time in human history people in any context can become educated via ubiquitous mobile learning.

Information and communication technologies (ICT) are the air the youngest generation (Gen $\mathrm{Z}$ ) has been breathing since their birth. They are technically savvy and cannot live without the constant access to ICT. Seven-year-old children are comfortable navigating an I-pad, computer, or smart phone. An average 15-year-old child, coming from a country measured by OECD, "had at least 5 years of experience using computers" [1, p. 38]. Members of Gen Z illustrate perfectly the truism that "It's only technology if it happens after you were born" [2].

Teachers must recognize the specifics of Gen Z, get prepared for them and be aware of the demands that ICT make on their time, and their abilities. New ICT empowers teachers to "engage students, gather their opinions, measure ... and even detect plagiarism" [3, p. 47]. ICT have gradually changed all aspects of education [4]. One example is the substitution of printed textbooks by smartphone applications e.g. in Finnish and Dutch schools.

As is true of many inventions, regardless of the intentions of their inventors, the actual production process often ends up in the hands of companies aiming at maximizing their own profits [5], leading to overuse or misuse, e.g., of food or drugs. Even without the profit motive at work, technological developments lead to unintended end places, with atomic power as an extreme example.

The danger of lack of awareness that there is a potential misuse of new ICT is probably even greater due to the sensitivity of a child's being [6]. Though its immediate negative effects may be subtle, their influence may take on unpredictable proportions. For example, children who spend more than 6 hours daily online outside of school are twice more likely to experience loneliness than moderate Internet users [1].

Many questions arise when working with students and technology simultaneously. How should teachers introduce ICT in their classrooms in a way that promotes learning? What do their young students already know about ICT? What does too much ICT look like in the classroom? [7]

Educators vary in their opinions regarding ICT use due to their diverse background experience. For illustration, when comparing teachers' use of computer programs, teachers in Slovakia use ICT more to review the acquired knowledge, whereas in England they develop comprehension and creativity [8]. Finnish teachers regard digital competency as being so important as their ability to speak their mother tongue [9].

\footnotetext{
* ${ }^{1}$ Dana Hanesova, ${ }^{2}$ Andrea Nelson, ${ }^{3}$ Ken Badley

${ }^{1}$ Faculty of Education, Matej Bel University, Banska Bystrica, Slovakia

${ }^{2}$ Humanities Department, Heppner High School, Heppner, USA

${ }^{3}$ Mount Royal University in Calgary, Canada

E-mail: dana.hanesova@umb.sk
} 
Reflecting the response to the potential of ICT in education, there is a continuum of approaches to ICT from techno-sceptical to techno-utopian. Our aim is to evaluate both poles in the light of research and then to scrutinize them from an ethical perspective.

\section{Techno-negative attitudes}

Techno-sceptics are people who warn against the negative influences of ICT upon children. They encourage educators to think carefully before becoming overly enthusiastic about ICT in education. Although he is more curious than sceptical himself, Poster's work has figured in techno-scepticism [5]. On his account, humans perceive information differently when that information is mediated by a screen. By inquiring into how information is transformed by the means of its transmission and reception, Poster places himself in a long tradition of observers running back to McLuhan, Ellul and Postman, all of whom have sounded similar cautions about uncritical use of technology.

Techno-sceptics state that massive use of ICT alters children's brain development and the structure of their abilities to think and learn (e.g. to remember facts [10]) as well as behave. Children's multitasking is associated with an increase in their attention deficit disorders [11]. To the OECD report [1], the overall impact of schools' investment in ICT has had only limited, even negative effects on students' performance (e.g. in reading, mathematics, science, or teaching foreign languages via ICT-assisted drills). ICT did not help to bridge the cognitive differences between advantaged and disadvantaged students.

Techno-sceptics worry about negative effects of virtual social networks on children's real-life social skills (e.g. to control and communicate emotions, solve real problems, find a partner, or prepare for a job [12]). A research into students' opinions showed their need for more human interaction during e-learning studies [13]. Researchers point also at a more frequent emergence of stress, insomnia, passivity, obesity or depression in children overusing ICT, and thus resulting in lowering their physical abilities and health condition [14 and 15].

The most radical techno-sceptics perceive high ICT use at a young age as the cause of permanent damage in children's lives. Based on international research, Spitzer [14] believes digital media actually lead to digital dementia (the term coined by Koreans [16]); decrease of children's spontaneity and creativity; and increase of technology addictions and of suicidal inclinations. He pleads for total exclusion of these media to 18 years of age in schools.

Not all techno-sceptics are so radical. Usually, in their blogs, they fight for more careful methodological considerations of ICT during lessons planning, and their evaluation. They ask ethical questions about the motives of ICT production and its research in schools.
Most of the mentioned studies were published when Gen $\mathrm{Z}$ was only beginning to be immersed in ICT as pupils. Though thousands of current studies indicate a relatively low influence of ICT in a traditional learning context, Hattie [17 and 18] expects increasing impact of ICT on the construction of knowledge via activating learning activities. As it is impossible to comprehend all impacts of new ICT on humans yet [19 and 20], only future research will show if negative findings continue to represent the realities of learning with ICT.

\section{Techno-positive attitudes}

Though being aware of the dangers of overwhelming digital power, techno-optimists see predominantly positive outcomes from ICT in education. Since the industrial revolution technoutopians have envisioned a world where machines removed the need for humans to work. Interestingly, the techno-dystopians have described their technological nightmares for about the same length of time. Where the poet, W. Blake, saw "Satanic mills" in his 1808 poem, "Jerusalem," others see a bright human future, made more humane by technology [21 and 22]. Nowadays many schools have high expectations from ICT [1].

Techno-utopians engage some techno-sceptics' arguments. For example, O'Gorman challenges the concept of digital dementia in connection with memory decrease due to heavy use of ICT and with the way of its diagnosis (primarily via self-reporting) [19]. He argues against the idea of its irreversibility, pointing at a potential for brain improvement as in cases of addiction. Instead of rote learning and focusing on the deterioration of lower-order thinking skill of storing/recalling information [23], techno-optimists are enthused over the positive influence of ICT on learning in a constructive way [24]. Research among Korean and Taiwanese teenaged students shows the increase of their motivation, higher thinking skills, and reduction of teachers' workload due to context-aware ubiquitous learning [15, 25, 23].

Another way how to positively process techno-sceptic data on alteration of the human mind under the influence of ICT is the techno-progressive stance, welcoming the symbiosis of technological and societal changes [26], and asking why not to perceive the 'digitally demented' brain structure as a stage in the process of brain enhancement. Of course, strong societies can be built only if ICT is used in just ways that benefit all members of that society.

Discussing the impact of the Internet on Gen Z' health, it has evidently become a source of information on a healthy lifestyle. Watching online sports broadcasts, e.g. of the Tour de France by Slovak youth, has had a real stimulating effect on their cycling activity. The recent phenomenon of getting children into outdoor physical movements in their search for a Pokémon is just one example of the necessity to find a proper balance in the use of technology. 
Most technophiles are aware of the necessity of thorough objective research of ICT influence [27], as well as of the requirements (such as adequate time, balance between ICT and teaching methods) of successful ICT implementation, attaining improvement of students' learning experience, or deep reading skills [28, 29 and 30$]$.

\section{Ethical reflections}

The mere existence of ICT does not present an ethical problem. It arises when asking: Who owns ICT? Who has the right to use them in children's lives? Why? To what extent? Every question in human life can be framed ethically even though it may focus primarily on another dimension. In that sense, educational uses of ICT are no different from other areas of human activity. Belar appeals to educators using ICT to consider its ethics [4]. Taking that advice, we consider it important that teachers consider seriously the ethical issues connected with ICT before their use in the classroom. They should be granted enough time for well-informed preparation, ethical self-reflection and critical thinking.

The core of the ethical question about the level of intensity and content provided by ICT in schools is the matter of responsibility for the holistic development of each child. Schultz ascribes the existence of an ethical problem to situations where there is a tension between the interests of various parties. The question is "which highest principle gives value to technologies" [31, p. 16]. Schultz associates ethics with the value of things, "providing each person with chances" [6, p. 348]. As values in cyber space are communicated via new forms of networking, humankind has found itself in the state of "educational twilight, as there is no new educational model adequate for the new era so far" [32, p. 257].

Educators have to realize that the following points must be treated as ethical questions:

The issue of power of technologies, of ICT producers and ICT owners. It lies in ICT forcing people "to reside in the cyberspace influencing their thinking, images and doing" whether they want or not [33, p. 257]. So either we can use our technologies or our technologies can use us [34].

The priority of children's needs for safe learning environments. Being in the development stage of concrete thinking, or just beginning to think analytically, children are not able of ethical reasoning to choose appropriate ICT, or to anticipate its dangers or benefits [35].

Character of research on ICT: Due to neoliberal pressures, research agencies are often controlled by performative or economic motives [36]. Of course, a few organizations have put significant effort into finding an objective impact of ICT on students.
Insufficient ethical preparation of teachers: In our survey, only 17 out of 4000 current studies deal with teachers' motives, attitudes, or values. Ethical dilemmas of ICT use are vastly neglected both in research and teacher education. Teachers should become aware of their motives to use ICT. Either they focus on the students' needs by preparing enjoyable, resourceful lessons or they are driven by personal professional, financial interests. Some teachers use ICT for its convenience, or out of fear of losing popularity among students, or by being pushed to use it by their authorities, and stressed out by its demands.

\section{Recommendations and conclusion}

Our aim was to highlight the importance of research and ethics of ICT use in the classroom, especially its impact on student's performance. According to OECD, education systems could "do more to improve the effectiveness of their investment into ICT by being both gradually accepting and sceptical" to ICT [1, p. 191].

In our classrooms we have encountered struggles finding the right balance between ICT use and traditional teaching methods. However, this new struggle is not that different from the struggles encountered by educators during paradigm shifts in education. Contemporary technologies are tools, similar to other educational tools, such as writing or textbooks. Every new technology, upon its introduction, engenders fears. We included writing just above because Plato addressed it in The Phaedrus over 2300 years ago, noting the fear expressed by some that people would forget how to remember if they could write things down. Humans have incorporated many new technologies since the development of writing, and each time that process of incorporation required negotiating a space between old and new.

Some teachers struggle to find a balance between bookwork and student-to-student engagement. Similarly, teachers, administrators and parents must find the right balance when using ICT. This takes a commitment from all stakeholders that they will reflect on their student growth goals and how ICT supports student learning. Too often assumptions are made that ICT will solve educational road blocks, when in reality it takes a community of student-focused individuals working together and using whatever tools are available to help their students succeed both academically and socially.

Also there is a need to put all effort into ensuring "that teachers have models of ICT use that correspond with each teacher's educational beliefs" [8, p.11]. To turn this vision into reality requires paying attention to high-quality teacher education and to building teacher professional communities, based on constructive discussions, regular tutoring, sufficient hands-on experience, and feedback.

We believe that-used correctly-ICT has the potential for good in schools. And, the corollary, used wrongly it can do harm. 
Some abused the new technologies while others used them for human flourishing. So this is why we call on educators, and on policy-makers to engage in careful ethical reflection before adopting new educational technologies.

\section{References}

[1] OECD. Students, Computers and Learning: Making the Connection. PISA:OECD, 2015.http:/dx.doi.org/10.17878/978926423955-en.

[2] LEVINE, A., DEAN, D. R.: It's only Technology if it Happens after You were Born, J. of College Admission, Summer 2013, 6-12. ISSN 0734-6670. http://files.eric.ed.gov/fulltext/EJ1011798.pdf.

[3] HART, A., HART, F. S.: The Digital Invasion. Grand Rapids: Baker Books, 2013. ISBN 978-0801015298.

[4] BELAR, C.: Technology and Education. Monitor on Psychology, vol. 43, No. 4, 2012, 75. ISSN 1529-4978.

[5] POSTER, M.: Information Please: Culture and Politics in the Age of Digital Machines. Durham, NC: Duke, 2006. ISBN 9780822338390.

[6] KELLY, K.: What Technology Wants. New York: Viking Penguin Group, 2010. ISBN 978-0-670-02215-1.

[7] COMBS, L. B., CENNAMO, K. S., NEWBILL, P. L.: Developing Critical and Creative Thinkers. Educational Technology, vol. 49, No. 5, 2009, 3-14. ISSN 0013-1962.

[8] LEEDER, G. P.: Computer Programs in Teaching at Secondary Schools (in Slovak), Final Thesis, Ruzomberok: KU, 2015.

[9] PAASO, A., KORENTO, K.: The Competent Teacher 2010-2020, Tampere: FNBE, 2010. ISBN 978-952-13-4436-7.

[10] SMALL, G., VORGAN, G.: i-Brain: Surviving the Technological Alteration of the Modern Mind, New York: Harper, 2009. ISBN 9780061340345.

[11] PALMER, S.: Toxic Childhood: How the Modern World is Damaging our Children and what we can do about it. London: Orion House, 2006. ISBN 9781409158714.

[12] PATRICK, A.: An Apple a Day Keeps Attention Away. The Technoskeptic, 20/04/2016. https://thetechnoskeptic.com/apple-aday/

[13] SULTANY, A., HALFORD, S.: Using a Techno-scepticism Framework to Evaluate the Perception and Acceptance of a New Online Reading, IADIS Intern. Conference e-Learning 2013, London: City University, 2013, 107-117. ISBN 978-972-8939-88-5. http://files. eric.ed.gov/fulltext/ED562300.pdf

[14] SPITZER, M.: Digital Dementia, Brno : Host, 2014. ISBN 978-80-7294-872-7.

[15] ZOLLINGER-READ, P.: How Technology and Inactive Lifestyles Are Changing Our Children. The Guardian, 30/08/2013. ISSN 0261-3077. https://www.theguardian.com/sustainable-business/technology-inactive-lifestyle-changing-children

[16] PARK, CHUNG-A.: Digital Dementia Troubles Young Generation, Korea Times, 08/06/2007. ISSN 1063-6412. http://www. koreatimes.co.kr/www/news/nation/2008/04/117_4432.html

[17] HATTIE, J.: Visible Learning, London : Routledge, 2009. ISBN 978-0415476188.

[18] HATTIE, J.: Ranking - Interactive Visualization, 2015. http://visible-learning.org/nvd3/visualize/hattie-rankinginteractive-2009-2011-2015.html

[19] O'GORMAN, M.: Taking Care of Digital Dementia, Ctheory.net, 18/02/2015. http://www.ctheory.net/articles.aspx?id=740

[20] WILLS, D.: Dorsality: Thinking Back through Technology and Politics, Minneapolis : UMP, 2008. ISBN 978-0816653461.

[21] GATES, B.: The Road Ahead, New York : Viking, 1995. ISBN 978-0670859139.

[22] KIM, J.: Techno-Skeptics and Techno-Utopians. 09/03/2014. Inside Higher Ed. https://www.insidehighered.com/blogs/ technology-and-learning/techno-skeptics-and-techno-utopians

[23] ANDERSON, L. W., KRATHWOHL, D. R. (Eds.): A Taxonomy for Learning, Teaching, and Assessing, Boston : Allyn \& Bacon, 2001. ISBN 978-0801319037.

[24] MUNZENMAIER, C., RUBIN, N.: Bloom's Taxonomy: What's old in new Again, Santa Rosa : The eLearning Guild, 2013. http:// educationalelearningresources.yolasite. com/resources/guildresearch_blooms2013\%20(1).pdf

[25] SHIH, J., CHU, H., HWANG, G.: An Investigation of Attitudes of Students and Teachers about Participating in a Contextaware Ubiquitous Learning Activity, British J. of Educational Technology, vol. 42, No. 3, 2011, 373-394. ISSN 1467-8535. DOI: 10.1111/j.1467-8535.2009.01020.x.

[26] Technoprogressive Declaration - Transvision 2014, Institute for Ethics and Emerging Technologies, 22/11/2014, http://ieet.org/ index.php/IEET/more/tpdec2014.

[27] KIRKWOOD, A., PRICE, A. Examining Some Assumptions and Limitations of Research on the Effects of Emerging Technologies, British J. of Educational Technology, vol. 44, No. 4, 2013, 536-543. ISSN 1467-8535. DOI: 10.1111/bjet.12049. 
[28] SAUNDERS, F. C., GALE, A. W.: Digital or Didactic: Using Learning Technology to Confront the Challenge of Large Cohort Teaching. British J. of Educational Technology, vol. 43, No. 6, 2012, 847-858. ISSN 1467-8535. DOI: 10.1111/j.14678535.2011.01250.x.

[29] RICHARDSON, J., WOLF, M.: Balance Technology and Deep Reading to Create Biliterate Children, Phi Delta Kappan, vol. 96, No. 3, 2014, 14-19. ISSN 1940-6487.

[30] OECD: Education at a Glance 2015: OECD Indictors. ISBN 9789264242098. http:/dx.doi.org/10.1787/eag-2015-en.

[31] SCHULTZ, R. A.: Contemporary Issues in Ethics and Information Technology, London : IRM Press, 2006. ISBN 1-59140-780-X.

[32] GALIK, S.: Current Issues of Educational Theory and Practice. In Contexts of Philosophy of Education in Modern Times and Contemporary Perspective. Kudlacova, B., Rajsky, A. (eds.) Trnava : PF TU, 2014, 250-258. ISBN. 9788080827724. See more: GOGORA, A.: Actor-network Theory and the Concept of Translation (in Slovak), Filosofia, vol. 68, No. 9, 800-811. ISSN 0046$385 \mathrm{X}$.

[33] OPPENHEIMER, R.: The Computer Delusion, Atlantic Monthly, vol. 280, No. 1, July 1997. ISSN 1072-7825. http://www. theatlantic.com/magazine/archive/1997/07/the-computer-delusion/376899/.

[34] POSTMAN, N.: Technopoly: The Surrender of Culture to Technology, New York : Knopf, 1992. ISBN 9780394582726.

[35] KOHLBERG, L.: Conscience as Principled Responsibility, Zecha, G., Weingartner, P. (eds.). Conscience: An Interdisciplinary View, Dordrecht : Riedel Publ. Comp., 1987, 3-15. ISBN 978-94-009-3821. Compare to: JUROVA, J.: On Etzioni’s Concept of a Responsive Community. European J. of Science and Theology, vol. 12, No. 3, 2016, 71-80. ISSN 1841-0464 and KONDRLA, P., KRALIK, R: Authentic Being and Moral Conscience. European J. of Science and Theology, vol. 12, No. 4, 2016, 155-164. ISSN 1841-0464. For more on this topic, see also: VALCOVA, K., PAVLIKOVA, M., ROUBALOVA, M.: Religious Existentialism as a Countermeasure to Moralistic Therapeutic Deism, Communications - Scientific Letters of the University of Zilina, vol. 18, No. 3, 2016, 98-104. ISSN 1335-4205. VALCO, M., KRALIK, R., BARRETT, L.: Moral Implications of Augustine's Philosophical and Spiritual Journey in his Confessiones. In: Communications - Scientific Letters of the University of Zilina, vol. 17, No. 2, 2015, 103-108. ISSN 1335-4205.

[36] AFEMANN, U.: Having a Laptop does not mean Education (in Germany), The European (Das Debaten-Magazin), 12/04/2011. http://www.theeuropean.de/uwe-afemann/6335-ikt-in-der-entwicklungszusammenarbeit. 